\title{
Biochemical characteristics of different forms of protein-energy malnutrition: an experimental model using young rats
}

\author{
By C. R. C. HEARD, SYLVIA M. FRANGI, PAULINE M. WRIGHT \\ Clinical Nutrition and Metabolism Unit, Department of Human Nutrition
}

\author{
AND P. R. McCARTNEY \\ Department of Medical Statistics and Epidemiology, London School of \\ Hygiene and Tropical Medicine, Keppel Street, London WCIE $7 H T$
}

$$
\text { (Received I I March r975-Accepted r6 May 1975) }
$$

I. In three separate experiments, four groups of five to eight young male rats were fed either (i) a high-protein diet, for which the net dietary protein : total metabolizable energy ratio (NDp : E) was 0.1 (HP diet); or (ii) a low-protein diet, for which NDp:E was 0.04 (LP diet). In both these groups, food intake was $a d$ lib. In group (iii) the HP diet was given in an amount approximately equal to that taken by the LP group fed ad lib. (HP-restricted). In group (iv) rats were fasted for $48 \mathrm{~h}$ after receiving the HP diet (HP-fasted). Each experiment lasted 4 weeks.

2. In the LP and HP-restricted groups, food intake was about $50 \%$ of that of the HP rats, while body-weight, after 4 weeks on diet was about $35 \%$ and $55 \%$ of that of HP rats, for LP and HP-restricted respectively. Both groups of malnourished rats gained some weight during the experiment.

3. Measurements of oral glucose tolerance and plasma insulin levels were made in the fourth week. LP and HP-restricted rats both showed low fasting insulin levels and low insulin to glucose ratios during the glucose tolerance tests; the LP rats were more seriously affected.

4. At the end of the fourth week the rats were killed and blood, liver and gastrocnemius muscle were analysed. LP rats showed specifically and consistently low values for haemoglobin and plasma protein concentration, and low activities of hepatic glucose-6-phosphatase ( $E C$ $3,1.3 .9)$ and of alanine aminotransferase $(E C$ 2.6.I.2) in liver and muscle. The activity of hepatic aspartate aminotransferase $(E C 2.6 . \mathrm{I}$. I ) was, if anything, increased. The plasma amino acid concentrations and ratios showed a specific fall in branched-chain amino acids. Liver fat concentration was consistently elevated. The HP-restricted rats had normal values for haemoglobin, plasma protein and liver fat, and near-normal values for plasma amino acids. Hepatic alanine aminotransferase showed increased activity compared with HP rats, but muscle alanine aminotransferase showed reduced activity. The HP-fasted rats had increased haemoglobin, plasma protein and liver fat concentration, and very low liver glycogen concentrations. Hepatic alanine aminotransferase activity was elevated. Plasma alanine concentration was specifically reduced.

5. The results are consistent with suppression of gluconeogenesis, liver dysfunction and essential amino acid deprivation in LP rats. These biochemical changes found in rats on a low intake of a diet of low protein and high carbohydrate value are similar to those found in kwashiorkor. An equally low intake of a diet of good protein value (HP-restricted) led to marginally better growth, accompanied by biochemical signs of increased gluconeogenesis, analogous to those reported for nutritional marasmus. This nutritional state was not biochemically identical with that of acute fasting.

6. The results are discussed in terms of the consistency of the rat model, and its contribution to understanding biochemical changes found in infant malnutrition.

In earlier work with young pigs, those fed on diets of low protein value showed abnormally high concentrations of glycogen in the liver and low activities of glucose6-phosphatase (EC 3.1.3.9) (Durbin, Heard \& Platt, I960; Heard, I966). Similar 
findings were reported for children suffering from kwashiorkor (Waterlow \& Weisz, 1956; Mukherjee \& Nath, r957). More recently Alleyne \& Scullard (I969) contradicted these findings claiming that low levels of hepatic glycogen and high glucose-6phosphatase activity were the rule in malnourished children. Similar discrepancies in other biochemical findings are numerous in the literature. It seemed to us that such 'contradictory' results must reflect adaptations to unknown variations in environmental factors, including differences in protein and energy intake.

It would therefore be helpful to establish patterns of adaptive changes characteristic of known dietary conditions.

This exercise requires the use of animal models, and for practical, economic reasons the rat would be the animal of choice. There has been a growing tendency to reject the rat because of its habit of restricting food intake on diets of poor nutritional value, and because efforts to produce the typical oedematous condition of kwashiorkor have been unsuccessful. However, as Waterlow \& Alleyne (1971) remark 'from a strict scientific point of view there is no real justification for putting the emphasis on oedema...since children with marasmus, as well as those with kwashiorkor, have increased amounts of body water'.

In the present work we have not aimed primarily at producing any preconceived collection of biochemical or clinical signs. We have set up a simple model which would represent four nutritional conditions which were well defined in respect to protein and energy intake, with the aim of establishing those biochemical patterns most characteristic of each nutritional state.

The experiments were carried out with young rats, as growth potential is essential to any reasonable model of infant malnutrition. The conditions investigated were: normal growth on a diet of high-protein value $(\mathrm{HP})$; severely restricted growth on a diet of low-protein value (LP); growth which was also severely restricted but this time because of restricted intake of the HP diet, which was 'pair-fed' in amounts approximately equal to the average intake of the LP diet (HP-restricted); acute loss of weight in previously well-nourished (HP) animals which were fasted for $48 \mathrm{~h}$ (HP-fasted).

The results showed a marked distinction between the LP and the HP-restricted groups analogous to the differences reported between well-defined kwashiorkor and marasmus respectively. Chronic undernutrition (HP-restricted) gave some but not all of the signs of acute food deprivation (HP-fasted). The reproducibility of this model was studied and gave confidence in its usefulness. Preliminary accounts of this work have been published (Broadbent \& Heard, r 973; Heard, Frangi \& Wright, r 973).

\section{EXPERIMENTAL}

\section{Diets}

The diets were based on casein, maize starch, dextrinized starch, arachis oil and cellulose, with appropriate additions of vitamins and salts. Variations in the protein content were achieved by alterations in the proportions of casein and starch. Gross protein content was kept at a relatively low level by supplementing the casein with methionine. These diets were first devised for experiments involving tube-feeding of 
Table I. Ratio, net dietary-protein energy:total metabolizable energy (NDP: $\mathrm{E}$ ) and composition $(g)$ of high-protein $(H P)$ and low-protein $(L P)$ diets given to rats

(Total weight (approximately I roo g) contains roo g cellulose (solka floc) and therefore represents $1000 \mathrm{~g}$ utilizable diet)

$\begin{array}{lcc} & \text { HP } & \text { LP } \\ \text { NDp:E } & 0.10 & 0.04 \\ \text { Water-soluble vitamin mix* } & \text { II } & \text { I I } \\ \text { Fat-soluble vitamin mix } & \text { I.0 } & \text { I.0 } \\ \text { Salt mix* } & 50 & 50 \\ \text { Arachis oil } & 50 & 50 \\ \text { Solka floct } & 100 & 100 \\ \text { Dextrinized maize starch } \ddagger & 300 & 300 \\ \text { Maize starch } & 469 & 549 \\ \text { Casein§ } & 120 & 40 \\ \text { L-Methionine } & 1 \cdot 0 & 0.5 \\ & 1102 \cdot 0 & \text { II0I.5 }\end{array}$

* Payne \& Stewart (1972).

† Solka floc (Johnsen, Jorgensen \& Wettre Ltd.).

I 'Mor-Sweet' Spray-dried glucose Syrup org24; Corn Products Ltd.

$\S$ 'Casumen', Prideaux Ltd.

Table 2. Numbers of animals in each group in experiments in which young rats were given either a high-protein (HP) diet ad lib., a low-protein (LP) diet ad lib., the HP diet pair-fed approximately to the intake of rats given the LP diet (HP-restricted), or the HP diet followed by a 48 fast (HP-fasted)

$\begin{array}{ccccc}\text { Experiment } & \text { HP } & \text { LP } & \text { HP-restricted } & \text { HP-fasted } \\ \text { I } & 6 & 6 & 6 & 6 \\ 2 & 6 & 6 & 6 & 6 \\ 3 & 5 & 8 & 7 & -\end{array}$

puppies and can be used as a $500 \mathrm{~g} / 1$ solution (C. R. C. Heard, unpublished results). Puppies and rats fed on these diets give well-formed stools, which is important in food intake or balance experiments.

Two diets were used. One designated 'high-protein' (HP) had a net dietary-protein: total metabolizable energy ratio (NDP:E) of $0 \cdot 10$ and the other, 'low-protein' (LP), a NDp: $\mathrm{E}$ of 0.04 (Table $\mathrm{I}$ ). The diets were given as dry powder. The NDp: $\mathrm{E}$ ratios of these diets $(0.04$ and 0.10$)$ do not correlate exactly with the gross protein contents $(4 \%$ and $12 \%$ ). This is because with increasing protein concentration an increasing proportion of the protein is not used for anabolic purposes and therefore does not qualify as 'net' dietary protein.

Four dietary regimens were used. They were: (1) HP given ad lib. (HP); (2) LP given ad lib. (LP); (3) HP pair-fed in amounts approximately equal to the average food consumption of the LP group (HP-restricted); (4) HP given ad lib., except for the last $48 \mathrm{~h}$ of the experiment, when food was withdrawn (HP-fasted). Three experiments were carried out. The numbers of rats and treatments in each experiment are shown in Table 2. 


\section{Animals}

Weanling male, black and white hooded Lister rats were used. They were housed individually in grid-bottomed cages, suspended over trays of sawdust in a room with a temperature of $23^{\circ}$ and controlled lighting and humidity. Sheets of filter-paper over the sawdust served to collect faeces and food spillage, when food intake was being measured. Water was available at all times. Food was supplied in earthenware pots fitted with a wire cover with a central hole which gave access to the food but minimized scattering.

On arrival from the supplier, rats were weighed and earmarked and all were fed on the HP diet for $2-3 \mathrm{~d}$ to accustom them to new surroundings and the powdered diet. They were then re-weighed and allocated to groups in such a way that the mean weight and range in each group was the same. Each rat was weighed two or three times/week and all rats were handled daily.

\section{Pair-feeding and food intakes}

At the beginning of each experiment weighed quantities of food were supplied in weighed food pots. The weight of food added, to maintain ad lib. feeding (HP, LP and HP-fasted), was noted on each occasion.

The apparent food consumption of the LP rats was measured daily by weighing the pot and remaining food and subtracting this value from the weight of the previous day's full pot. This value overestimated food intake by the extent of the spillage. Where necessary an estimate of spillage was made visually and allowance for this made in deciding the mean $24 \mathrm{~h}$ food intake of the LP rats. This amount of the HP diet was then weighed out for each rat in the HP-restricted group for the following day. Amounts supplied for feeding on Saturday and Sunday were deduced from the preceding 5 days' intake.

Actual, as distinct from apparent, food intake was determined every $7 \mathrm{~d}$ for all animals. Material collected on filter-papers under each tray was sieved to separate the spilt powdered food from faeces. The sieved food was weighed and this weight was subtracted from the apparent food intake, i.e. the weight of food which had disappeared from the food pot over the $7 \mathrm{~d}$.

\section{Insulin: glucose ratio $(I / G)$ during glucose tolerance tests $(G T T)$}

Rats were fasted for 5 or $17 \mathrm{~h}$ and then transferred to the laboratory. During the GTT they were in a cage with water available and kept warm under an infra-red lamp. A fasting blood sample $(0.02$ or $0.05 \mathrm{ml})$ for glucose estimation was taken from the tail by cutting the tip and gently stroking. A further small blood sample was taken into a heparinized tube for plasma insulin estimation. After each bleeding, the tails were dipped in $60 \%$ alcohol.

Glucose $(\mathrm{I} \cdot 6 \mathrm{~g} / \mathrm{kg}$ body-weight) was administered by stomach tube (Woodnott, I $96 \mathrm{I}$ ) as a 0.5 or $0.6 \mathrm{~g} / \mathrm{ml}$ solution, to the unanaesthetized animal. In animals accustomed to being handled by the experimenter this procedure and subsequent bleeding 
had no effect on blood glucose and plasma insulin concentrations, when saline instead of glucose was administered.

After the glucose load, blood samples were taken at intervals up to $2 \mathrm{~h}$ for measurement of blood glucose and plasma insulin concentrations. Usually blood glucose and plasma insulin values had returned to fasting levels within $\mathrm{I} h$ of giving glucose, and since some of the rats were difficult to bleed after $\mathrm{I} h$ it was decided to use only the first hour of the GTT to assess plasma insulin concentrations in relation to the blood glucose levels. This was done by determining the ratio $(\mathrm{I} / \mathrm{G})$ of mean plasma insulin level to the mean blood glucose level. Mean values for the hour were calculated by determining the mean value for each $15 \mathrm{~min}$ period and averaging these means, i.e. if $G_{0}, G_{15}, G_{30}, G_{45}$ and $G_{60}$ are the blood glucose concentrations at $0,15,30,45$ and 60 min, the mean blood glucose value for the hour was taken as:

$$
\frac{\left(G_{0}+G_{15}\right)}{2}+\frac{\left(G_{15}+G_{30}\right)}{2}+\frac{\left(G_{30}+G_{45}\right)}{2}+\frac{\left(G_{45}+G_{60}\right)}{2} \div 4 \text {. }
$$

Insulin values were treated similarly.

To assess the possibility that increment in glucose and insulin concentrations might be more important than absolute values, similar calculations were made for $\mathrm{I} / \mathrm{G}$ using increments above fasting values rather than absolute concentrations.

\section{Post-mortem examinations and analytical methods}

After a $5 \mathrm{~h}$ fast rats were anaesthetized with chloroform. As soon as breathing stopped the chest was opened and blood removed from the heart with a heparinized syringe. This blood was sampled for haemoglobin and glucose, and was then centrifuged to remove plasma, which was immediately frozen in solid $\mathrm{CO}_{2}$ and stored at $-20^{\circ}$. Meanwhile a second operator removed the liver and the gastrocnemius muscle of each hind leg. These samples were blotted free of blood, placed in small polythene bags, frozen in solid $\mathrm{CO}_{2}$ and also stored at $-20^{\circ}$.

Blood glucose was measured with glucose oxidase using the 'GOD-Perid' assay kit of Boehringer Corporation (London) Ltd, with uranyl acetate as the proteinprecipitating agent.

Plasma insulin was measured by the radioimmunoassay method of Hales \& Randle (1963) using the kit supplied by the Radiochemical Centre, Amersham. Bound insulin was separated by filtration. The volume of all reagents was halved to allow duplicate analysis of $50 \mu \mathrm{l}$ aliquots of plasma samples. Serial dilutions of rat plasma of high insulin content gave dose-response curves parallel with those for the standard solutions of crystalline bovine insulin. Plasma samples and standard insulin solutions were stored at $-20^{\circ}$.

Haemoglobin was measured by the cyanmethaemoglobin method (Wootton, 1964).

Plasma protein was measured by the biuret method (Wootton, 1964).

Plasma amino acids were measured on a Locarte amino acid analyser (Floor model; The Locarte Company, 199 North End Road, London W I4). Equal volumes of plasma from each of three rats from each group in each experiment were combined and the pooled samples analysed. 
Water content of the livers was measured by oven-drying at $100^{\circ}$.

Fat content of the livers was measured in a weighed, powdered, dry sample of liver by overnight extraction at room temperature into a mixture of diethyl ether, petroleum ether (b.p. $\left.40^{\circ}-60^{\circ}\right)$ and ethanol $(5: 5: 2, \mathrm{v} / \mathrm{v})$. This extract, and subsequent solvent washings of the liver powder, were combined and evaporated to dryness and the weight of fat determined (Doell, I966).

Glycogen and glucose-6-phosphatase were measured in separate samples of frozen tissue by the methods of Kemp \& Kits van Heijningen (1954) and Freedland \& Harper (1958), repectively.

Aspartate aminotransferase $(E C$ 2.6.1 . 1 $)$ and alanine aminotransferase $(E C 2.6 .1 .2)$ were measured in frozen samples of liver and muscle. The weighed tissue was homogenized in distilled water in a glass homogenizer (Duall Size 22; Kontes Glass Company, Vineland, N.J.) (I/roo dilution) and further dilutions were assayed for aminotransferase activity by Reitman \& Frankel's (1957) method for serum, using the colorimetric GOT/GPT assay kit of Boehringer Corporation (London) Ltd.

\section{Statistical methods}

Three experiments were carried out using the dietary treatments described above. Analysis of variance was carried out on the results where appropriate. The design is not orthogonal (mainly due to a missing cell in the third experiment, see Table 2) and in some cases it was necessary to transform the response variable to stabilize the variance. The model was of the form:

$$
\begin{aligned}
\text { Response variable }= & \text { constant } \\
& + \text { diet effect } \\
& + \text { experiment effect } \\
& + \text { diet-experiment interaction } \\
& + \text { residual error. }
\end{aligned}
$$

This was fitted by regression methods.

The first response variable to be examined was food intake (we use the term 'response' loosely here since food intake was controlled in one of the diets). Unfortunately this was found to have a significant interaction implying that food intake differences were not constant in the three experiments. As this could affect other responses, the procedure was slightly altered in subsequent analyses. When interaction was significant for a particular response variable the analysis was repeated, adding food intake as a covariate to the model. If this addition had the effect of reducing the interaction to insignificance then it is reasonable to assume that the different food intakes were a likely cause of the difference in diet effects found between experiments. If the food intake addition did not reduce the interaction accordingly then we can only say that the diet effects were not of the same size in the three experiments. It is important to note that significant interaction does not imply that the diet effects were inconsistent in direction, although this may be so, merely that the diet effects were not of the same magnitude (i.e. did not fit the model) in the three experiments.

In the tables of results, means and standard errors are given for each group in each 
Table 3. Food intake and body-weight gain of young rats given for 4 weeks either a highprotein $(H P)$ diet ad lib., a low-protein $(L P)$ diet ad lib., or the HP diet pair-fed approximately to the intake of the rats given the LP diet (HP-restricted)

(Mean values with their standard errors)

\begin{tabular}{|c|c|c|c|c|c|c|c|}
\hline \multirow[b]{2}{*}{ Measurement } & \multirow[b]{2}{*}{ Expts } & \multicolumn{2}{|c|}{ HP } & \multicolumn{2}{|c|}{ LP } & \multicolumn{2}{|c|}{ HP-restricted } \\
\hline & & Mean & SE & Mean & SE & Mean & $\mathrm{SE}$ \\
\hline $\begin{array}{l}\text { Food intake } \\
\text { (g/rat per } 28 \mathrm{~d})\end{array}$ & $\begin{array}{l}1 \\
2 \\
3\end{array}$ & $\begin{array}{l}390 \\
473 \\
447\end{array}$ & $\begin{array}{r}20.2 \\
3.8 \\
6.5\end{array}$ & $\begin{array}{l}244 \\
274 \\
175\end{array}$ & $\begin{array}{r}10.7 \\
4.1 \\
8.3\end{array}$ & $\begin{array}{l}196 \\
269 \\
197\end{array}$ & $\begin{array}{l}3.0 \\
0.9 \\
I \cdot I\end{array}$ \\
\hline $\begin{array}{l}\text { Body-weight gain* } \\
\text { (g/rat per } 28 \mathrm{~d} \text { ) }\end{array}$ & $\begin{array}{l}\text { I } \\
2 \\
3\end{array}$ & $\begin{array}{l}\text { I } 8 \\
\text { I } 43 \\
\text { I } 41\end{array}$ & $\begin{array}{l}7 \cdot 9 \\
5 \cdot 0 \\
3 \cdot 3\end{array}$ & $\begin{array}{l}8 \cdot 5 \\
8 \cdot 8 \\
7 \cdot 1\end{array}$ & $\begin{array}{l}1.0 \\
2.5 \\
1.6\end{array}$ & $\begin{array}{l}45 \\
42 \\
36\end{array}$ & $\begin{array}{l}2 \cdot 4 \\
1 \cdot 5 \\
2 \cdot 9\end{array}$ \\
\hline
\end{tabular}

* The initial body-weights for all groups combined in the three experiments were ( $g$, mean $\pm S E)$ :

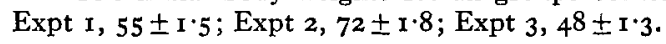

experiment. These are accompanied by a brief statement of the results of analysis of variance (Table Io). The numbers of response variables measured precludes giving full details of the statistical analysis. The numbers of animals in each experiment are shown in Table 2.

\section{RESULTS}

\section{Food intake and body-weight gain}

The LP groups consumed on average only $55 \%$ as much food as did the HP groups and therefore only $18 \%$ as much protein (Table 3 ). Growth was minimal being only $7 \%$ of that achieved by the HP rats. With a similarly low energy intake, but with protein intake raised to about $50 \%$ of that of the HP group, the HP-restricted group achieved growth to the extent of $30 \%$ of that of the HP rats (Fig. I). The pattern in weight gain obviates the need for further statistical analysis; the table speaks for itself (Table 3 ; Fig. I).

The variation in food intake has already been noted in the previous section and this was largely due to the fact that the pair-feeding procedure was only approximate and quantitative details could be calculated only in retrospect.

\section{Blood values}

Haemoglobin. The three experiments agreed in placing the mean haemoglobin concentrations for each group in each experiment in the following order: HP-fasted $>\mathrm{HP}$-restricted $\simeq \mathrm{HP}>\mathrm{LP}$ (Table 4 ). The degree of anaemia in the LP rats was not severe, except in Expt 3 in which the rats were smaller and younger when placed on the experimental diets than in Expts $I$ and 2.

Plamsa proteins. The results for plasma proteins closely paralleled those for haemoglobin (Table 4). Again hypoproteinaemia was most severe in the LP rats of Expt 3. Interaction just achieved statistical significance ('Table ro) which was explained by food intake. However, its effect was not large. 


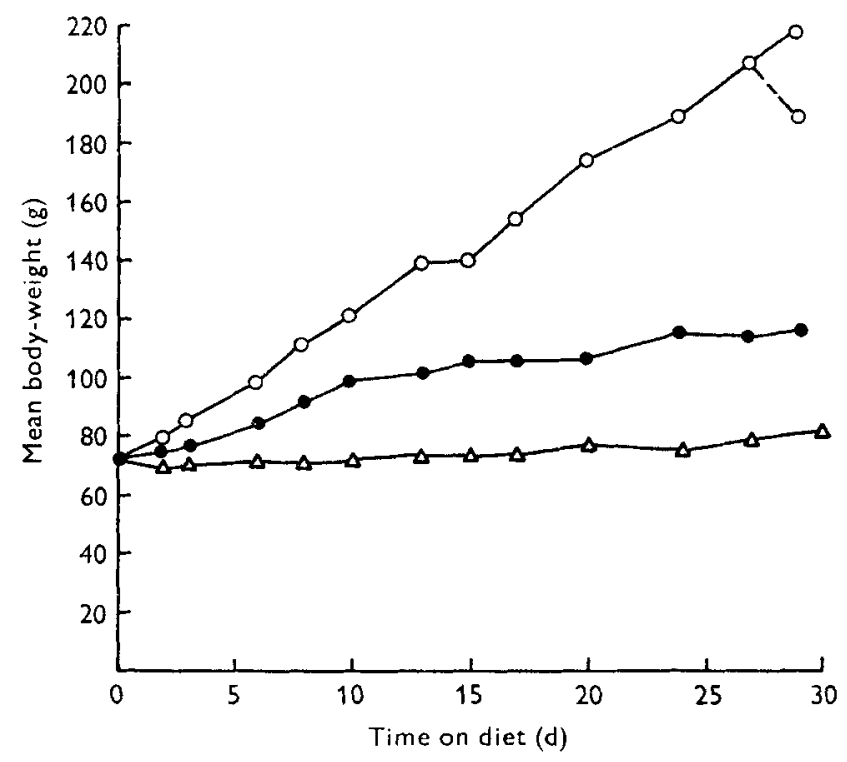

Fig. 1. Mean changes in body-weight of rats given for 4 weeks diets of different protein or energy value (Expt 2). $\mathrm{O}$, High protein (HP) diet fed ad lib.;, $\mathrm{HP}$ diet pair-fed to the intake of rats given the low-protein (LP) diet; $\triangle, \mathrm{LP}$ diet fed ad lib.; $\bigcirc-\cdots---\mathrm{O}$, effect of $48 \mathrm{~h}$ fasting on rats given the HP diet.

Table 4. Haemoglobin, plasma protein, blood glucose and plasma insulin concentrations in young rats given for 4 weeks either a high-protein $(H P)$ diet ad lib., a low-protein $(L P)$ diet ad lib., the HP diet pair-fed approximately to the intake of the rats given the LP $\operatorname{diet}(H P$-restricted), or the HP diet ad lib., followed by a 48 h fast (HP-fasted). The HP, $L P$ and HP-restricted rats were fasted for $5 h$ before killing

(Mean values with their standard errors)

\begin{tabular}{|c|c|c|c|c|c|c|c|c|c|}
\hline \multirow[b]{2}{*}{ Measurement } & \multirow[b]{2}{*}{ Expt } & \multicolumn{2}{|c|}{$\mathrm{HP}$} & \multicolumn{2}{|c|}{ LP } & \multicolumn{2}{|c|}{ HP-restricted } & \multicolumn{2}{|c|}{ HP-fasted } \\
\hline & & Mean & SE & Mean & SE & Mean & sE & Mean & SE \\
\hline \multirow[t]{3}{*}{ Haemoglobin $(g / 1)$} & I & 123 & $3 \cdot 2$ & II 2 & 9.0 & 130 & 5.5 & 160 & 2.7 \\
\hline & 2 & I 29 & $1 \cdot 4$ & 102 & $3 \cdot 3$ & 132 & 3.9 & 144 & $4 \cdot x$ \\
\hline & 3 & $x 26$ & $7 \cdot 4$ & 87 & 6.5 & 125 & $7 \cdot 3$ & - & - \\
\hline \multirow[t]{3}{*}{ Plasma protein $(\mathrm{g} / \mathrm{l})$} & I & 66 & $x \cdot 8$ & 58 & $3^{* I}$ & 65 & $3 \cdot 8$ & 74 & 0.7 \\
\hline & 2 & 77 & $2 \cdot 2$ & 56 & $I \cdot 2$ & $8 \mathrm{I}$ & $3 \cdot 4$ & 80 & $4 \cdot 3$ \\
\hline & 3 & 56 & $I \cdot 9$ & 37 & $I \cdot 8$ & 54 & $2 \cdot 0$ & - & - \\
\hline \multirow[t]{3}{*}{ Blood glucose $(\mathrm{g} / \mathrm{l})$} & $\mathbf{I}$ & I. O9 & 0.036 & $I \cdot 20$ & 0.052 & $I \cdot 02$ & 0.064 & $I \cdot 09$ & 0.036 \\
\hline & 2 & $I \cdot I 8$ & 0.056 & $I \cdot I 5$ & 0.073 & $I \cdot 35$ & 0.088 & 0.91 & 0.033 \\
\hline & 3 & 0.92 & 0.184 & 0.75 & 0.073 & 0.79 & 0.110 & 一 & - \\
\hline \multirow[t]{3}{*}{ Plasma insulin $(\mathrm{mU} / \mathrm{l})$} & I & 47 & $9 \cdot I$ & 15 & $2 \cdot 6$ & 24 & $2 \cdot 4$ & 23 & 3.0 \\
\hline & 2 & 50 & $6 \cdot 3$ & 23 & 5.4 & I9 & $I \cdot 7$ & 24 & $2 \cdot 5$ \\
\hline & 3 & 30 & $1 \cdot 8$ & 9 & 0.9 & I6 & $3 \cdot 1$ & - & - \\
\hline
\end{tabular}




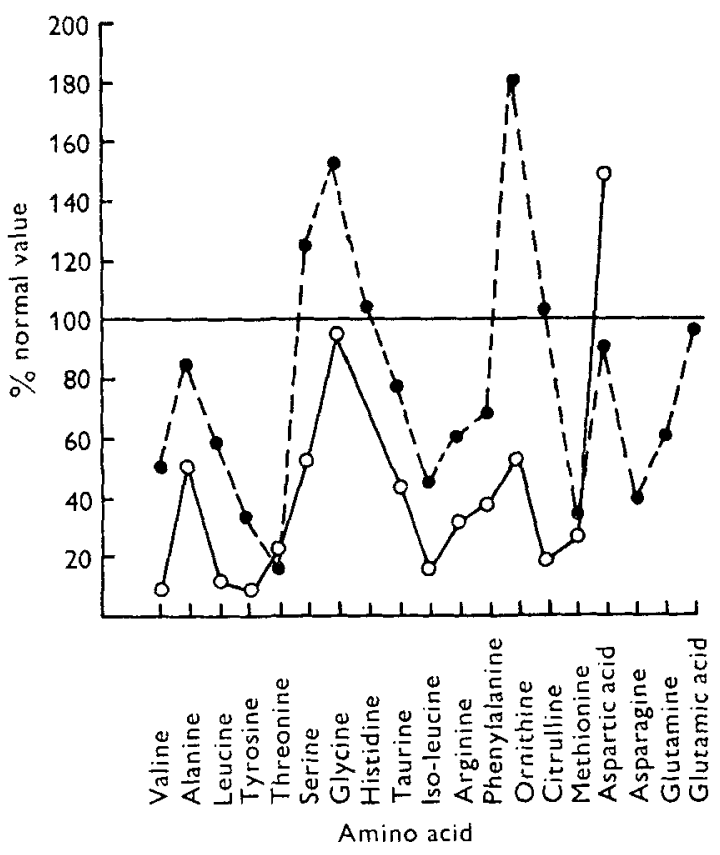

Fig. 2. Plasma amino acid concentrations, as percentages of normal values. $\bigcirc$, Malnourished child (protein-energy malnutrition); $\bigcirc$, young rats fed for 4 weeks on a low-protein diet (LP). Results for the malnourished child are from Holt, Snyderman, Norton, Roitman \& Finch (1963) and for LP rats from Broadbent \& Heard (r973).

Fasting blood glucose and plasma insulin. There was no effect of diet on blood glucose concentrations (Table 4 ), but the effect on the fasting plasma insulin concentration was highly significant. Plasma insulin was reduced in all three malnourished groups in each of the three experiments. In two of the three experiments the LP rats had lower fasting insulin concentrations than those in the HP-restricted group.

Plasma amino acids. The concentrations of 20 amino acids were calculated from pooled blood samples and the results are presented graphically with the mean values for the LP, HP-restricted and HP-fasted rats expressed as a percentage of the values of the HP rats. The absolute values found in the HP rats have already been reported (Broadbent \& Heard, I973).

Fig. 2 shows the results for the LP rats compared with those for a severely malnourished child, and indicates the similarity in plasma amino acid pattern. The most notable features of this pattern are subnormal concentrations of branched-chain amino acids (valine, leucine and isoleucine), tyrosine, threonine and methionine, with preservation and even elevation of the concentration of a number of non-essential amino acids. This imbalance is revealed also in the significantly elevated $(P=0.01)$ non-essential:essential amino acid ratio (N:E) observed in LP rats ('Table 5).

Fig. $3(a)$ compares this pattern of amino acids found in the plasma of LP rats with that found in the plasma of the HP-restricted animals. The normal pattern is much more nearly maintained in the latter condition, so that $\mathrm{N}: \mathrm{E}$ is also nearer normal. Fig. $3(b)$ confirms that the amino acid pattern of chronically energy-restricted 

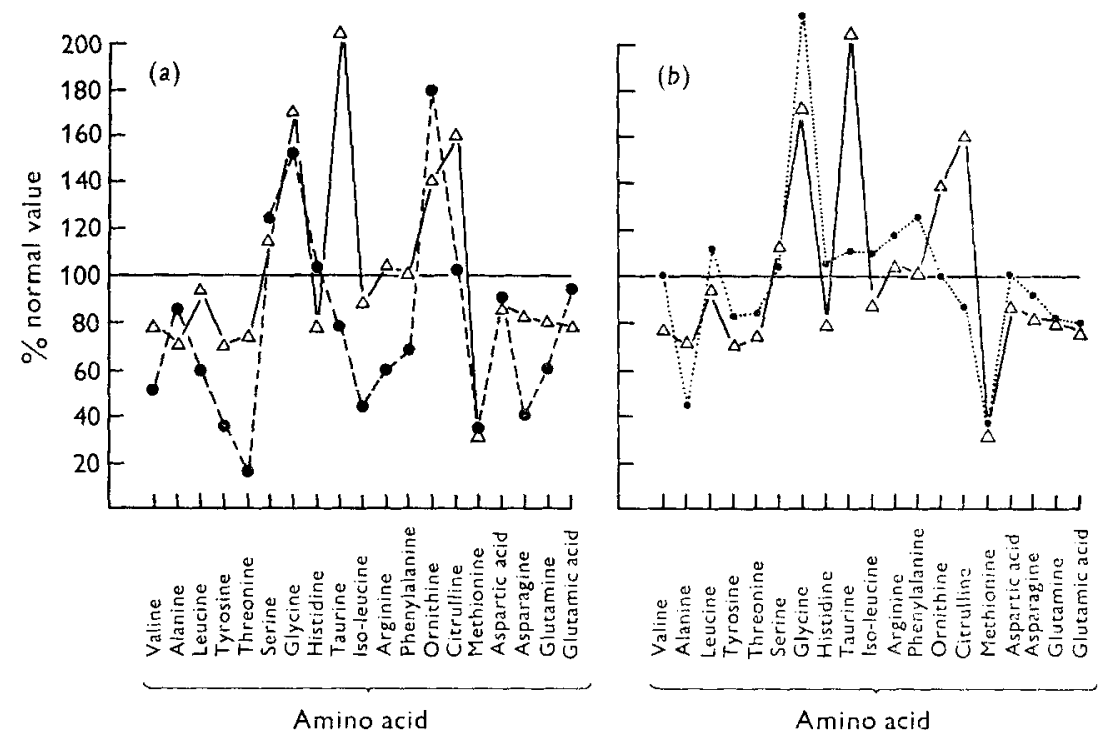

Fig. 3. Plasma amino acid concentrations of rats given diets of different energy and protein value. Values are expressed as percentages of concentrations found in control animals given a high-protein (HP) diet ad lib. (a) ○, Low-protein (LP) diet ad lib.; $\triangle$, the HP diet pair-fed approximately to the intake of the rats given the LP diet (HP-restricted); $(b)$ ad lib., followed by $48 \mathrm{~h}$ fasting (HP-fasted); $\triangle, \mathrm{HP}$-restricted.

Table 5. Mean molar ratios ( $\pm \mathrm{SE}$ ) for non-essential $(N)$ :essential $(E)$ amino acids $(N: E)$ and for phenylalanine: tyrosine in pooled samples of plasma from young rats (Expts $\mathrm{I}$ and 2 ) given for 4 weeks either a high-protein (HP) diet ad lib., a low-protein (LP) diet ad lib., the HP diet pair-fed approximately to the intake of the rats given the LP diet (HPrestricted), or the HP diet followed by a $48 \mathrm{~h}$ fast (HP-fasted). The HP, LP and HPrestricted rats were fasted for 5 before killing

\begin{tabular}{|c|c|c|c|c|c|}
\hline Diet $\quad .$. & & $\mathrm{HP}$ & LP & HP-restricted & HP-fasted \\
\hline No. of samples $\ldots$ & & 3 & 3 & 3 & 2 \\
\hline No. of rats $\ldots$ & & 9 & 9 & 9 & 6 \\
\hline $\mathrm{N}: \mathrm{E}^{*}$ & $\begin{array}{l}\text { Mean } \\
\text { SE }\end{array}$ & $\begin{array}{l}2 \cdot 49 \\
0.139\end{array}$ & $\begin{array}{l}4.44 \\
0.278\end{array}$ & $\begin{array}{l}3.52 \\
0.095\end{array}$ & $\begin{array}{l}2 \cdot 87 \\
0 \cdot 285\end{array}$ \\
\hline $\begin{array}{l}\text { Phenylalanine: } \\
\text { tyrosine }\end{array}$ & $\begin{array}{l}\text { Mean } \\
\text { SE }\end{array}$ & $\begin{array}{l}0.61 \\
0.047\end{array}$ & $\begin{array}{l}I \cdot 20 \\
0.015\end{array}$ & $\begin{array}{l}0.92 \\
0.154\end{array}$ & $\begin{array}{l}0.92 \\
0.035\end{array}$ \\
\hline
\end{tabular}

* $\mathrm{N}=$ sum of concentrations $(\mu \mathrm{mol} / \mathrm{l})$ of taurine, serine, glutamine and glycine. $\mathrm{E}=$ sum of concentrations $(\mu \mathrm{mol} / 1)$ of valine, methionine, isoleucine and leucine.

(HP-restricted) rats is qualitatively very similar to that in the plasma of rats which were acutely fasted after previously being adequately nourished (HP-fasted).

In regard to the phenylalanine: tyrosine ratio, it was again the $L P$ rats which showed the greatest deviation from normal (Table 5).

\section{Liver composition}

The fat content of the liver showed a distinct pattern in relation to diet: LP $>$ HPfasted $>\mathrm{HP} \simeq \mathrm{HP}$-restricted (Table 6 ). The glycogen content was very variable (Table 6), but in livers of the acutely fasted rats it was always very much lower than 
Table 6. Fat and glycogen content and activities of glucose-6-phosphatase $(E C 3 \cdot 1 \cdot 3 \cdot 9)$, aspartate aminotransferase (EC 2.6. I . I) and alanine aminotransferase (EC 2.6. I.2) in the livers of young rats given for 4 weeks either a high-protein (HP) diet ad lib., a lowprotein (LP) diet ad lib., the HP diet pair-fed approximately to the intake of rats given the LP diet (HP-restricted), or the HP diet followed by a 48 h fast ( $H P$-fasted $)$. The HP, $L P$ and HP-restricted rats were fasted for $5 h$ before killing

(Mean values with their standard errors)

\begin{tabular}{|c|c|c|c|c|c|c|c|c|c|}
\hline \multirow[b]{3}{*}{ Measurement } & \multirow[b]{3}{*}{ Expt } & \multicolumn{8}{|c|}{ Diet } \\
\hline & & \multicolumn{2}{|c|}{$\mathrm{HP}$} & \multicolumn{2}{|c|}{ LP } & \multicolumn{2}{|c|}{ HP-restricted } & \multicolumn{2}{|c|}{ HP-fasted } \\
\hline & & Mean & SE & Mean & SE & Mean & $\mathrm{SE}$ & Mean & SE \\
\hline Fat (mg/g dry wt) & $\begin{array}{l}1 \\
2 \\
3\end{array}$ & $\begin{array}{r}103 \\
85 \\
116\end{array}$ & $\begin{array}{l}7 \cdot 2 \\
6 \cdot 7 \\
6 \cdot 1\end{array}$ & $\begin{array}{l}180 \\
227 \\
245\end{array}$ & $\begin{array}{l}13.9 \\
10.6 \\
15.2\end{array}$ & $\begin{array}{r}98 \\
104 \\
100\end{array}$ & $\begin{array}{l}5 \cdot 2 \\
4 \cdot 8 \\
6 \cdot 8\end{array}$ & $\begin{array}{l}\text { I3I } \\
\text { I59 } \\
-\end{array}$ & $\begin{array}{l}7 \cdot 5 \\
6.8 \\
- \\
\end{array}$ \\
\hline Glycogen $(\mathrm{mg} / \mathrm{g})$ & $\begin{array}{l}1 \\
2 \\
3\end{array}$ & $\begin{array}{l}50 \\
56 \\
18\end{array}$ & $\begin{array}{r}5 \cdot 9 \\
11 \cdot 2 \\
5 \cdot 3\end{array}$ & $\begin{array}{l}57 \\
70 \\
12\end{array}$ & $\begin{array}{l}4.4 \\
7.5 \\
2.0\end{array}$ & $\begin{array}{r}59 \\
18 \\
7\end{array}$ & $\begin{array}{l}3 \cdot 3 \\
2 \cdot 3 \\
3 \cdot 7\end{array}$ & $\begin{array}{l}9.8 \\
4.4 \\
-\end{array}$ & $\begin{array}{r}2.3 \\
0.6 \\
\end{array}$ \\
\hline $\begin{array}{l}\text { Glucose- } 6- \\
\text { phosphatase (units } / \mathrm{g} *\end{array}$ & $\begin{array}{r}1 \\
2 \\
3\end{array}$ & $\begin{array}{l}17 \cdot 4 \\
19 \cdot 1 \\
11.8\end{array}$ & $\begin{array}{l}0.9 \\
0.9 \\
2.3\end{array}$ & $\begin{array}{r}13.8 \\
11.6 \\
4.4\end{array}$ & $\begin{array}{l}0.8 \\
0.5 \\
0.4\end{array}$ & $\begin{array}{l}19 \cdot 7 \\
21 \cdot 2 \\
18 \cdot 2\end{array}$ & $\begin{array}{l}0.8 \\
0.7 \\
3.0\end{array}$ & $\begin{array}{l}16.6 \\
17.3 \\
-\end{array}$ & $\begin{array}{l}2.9 \\
0.5 \\
-\end{array}$ \\
\hline $\begin{array}{l}\text { Aspartate amino } \\
\text { transferase (units/g*) }\end{array}$ & $\begin{array}{l}1 \\
2 \\
3\end{array}$ & $\begin{array}{l}33 \cdot 7 \\
22 \cdot 1 \\
23 \cdot 8\end{array}$ & $\begin{array}{l}3.9 \\
1.5 \\
2.6\end{array}$ & $\begin{array}{l}35.0 \\
38.8 \\
33.4\end{array}$ & $\begin{array}{l}4 \cdot 8 \\
3 \cdot 3 \\
3 \cdot 3\end{array}$ & $\begin{array}{l}40.6 \\
50.4 \\
39.8\end{array}$ & $\begin{array}{l}3.0 \\
2.9 \\
3.6\end{array}$ & $\begin{array}{l}55.4 \\
49.4 \\
-\end{array}$ & $\begin{array}{l}4 \cdot 1 \\
7 \cdot 2 \\
\end{array}$ \\
\hline $\begin{array}{l}\text { Alanine amino } \\
\text { transferase (units/g*) }\end{array}$ & $\begin{array}{l}1 \\
2 \\
3\end{array}$ & $\begin{array}{r}10.2 \\
7.6 \\
7.0\end{array}$ & $\begin{array}{l}0.9 \\
I \cdot 2 \\
I-3\end{array}$ & $\begin{array}{l}4 \cdot 7 \\
1 \cdot 7 \\
2 \cdot 2\end{array}$ & $\begin{array}{l}1.2 \\
0.4 \\
0.6\end{array}$ & $\begin{array}{l}16.2 \\
23.9 \\
16.4\end{array}$ & $\begin{array}{l}I \cdot 5 \\
2.6 \\
3.0\end{array}$ & $\begin{array}{l}21 \cdot 6 \\
15.6 \\
-\end{array}$ & $\begin{array}{l}3 \cdot 6 \\
x \cdot 1 \\
-\end{array}$ \\
\hline
\end{tabular}

* I unit of enzyme is that amount which catalyses the transformation of I micromole of the substrate per minute under standard conditions (see Methods).

that of any other group, and this probably accounts for the significant diet effect. For both fat and glycogen a significant interaction which was not explained by food intake differences, reflects the variation in the size of the diet effects (Table 10).

\section{Liver enzymes}

Glucose-6-phosphatase. In each experiment the LP rats had the lowest activity and the HP-restricted group the highest (Table 6). The order of mean enzyme activity for the four groups in each experiment was: HP-restricted $>\mathrm{HP}>\mathrm{HP}$-fasted $>\mathrm{LP}$. This order is the reverse of that found for liver fat.

Aspartate aminotransferase. Mean activities of this enzyme were in the order: HP-fasted $>$ HP-restricted $>$ LP $>$ HP (Table 6). The differences were not large compared with the standard errors but were almost completely consistent in direction, implying reasonable reliability.

Alanine aminotransferase. There were marked differences in the activity of this enzyme (Table 6); that of the HP-restricted group being very much above the HP value, and that of the LP rats equally below. The only inconsistency was between the HP-restricted and HP-fasted rats. The order of activity was $\mathrm{HP}$-fasted $\simeq \mathrm{HP}$ restricted $>\mathrm{HP}>\mathrm{LP}$. 
Table 7. Activities of aspartate aminotransferase (EC 2.6.1.1) and alanine aminotransferase (EC 2.6.I.2) in the muscle of young rats given for 4 weeks either a highprotein (HP) diet ad lib., a low-protein (LP) diet ad lib., the HP diet pair-fed approximately to the intake of the rats given the LP diet (HP-restricted) or the HP diet followed by a $48 h$ fast (HP-fasted). The HP, LP and HP-restricted rats were fasted for $5 h$ before killing

(Mean values with their standard errors)

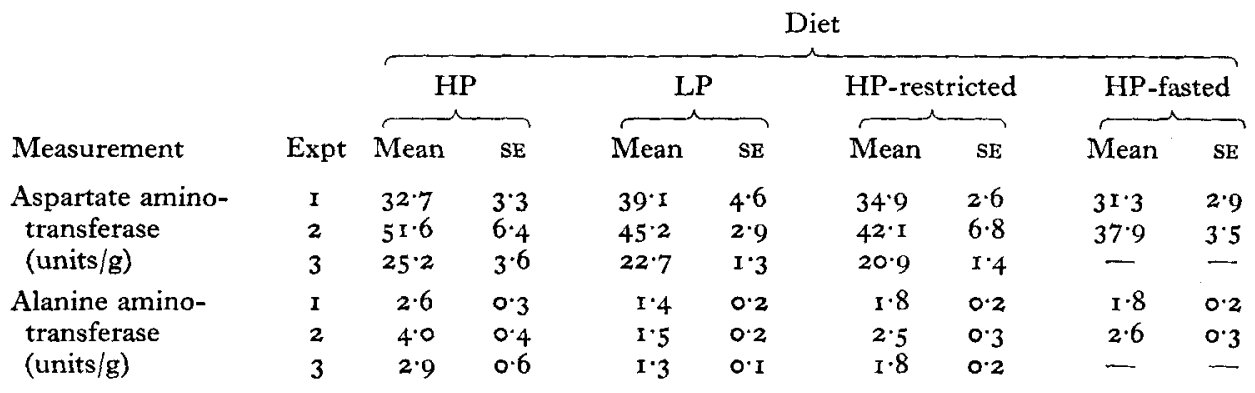

Table 8. Blood glucose and plasma insulin levles during the first hour of oral glucose tolerance tests in young rats, given either a high-protein (HP) diet ad lib., a low-protein (LP) diet ad lib., or the HP diet pair-fed approximately to the intake of rats given the LP diet (HP-restricted) for 3-4 weeks

(Mean values with their standard errors)

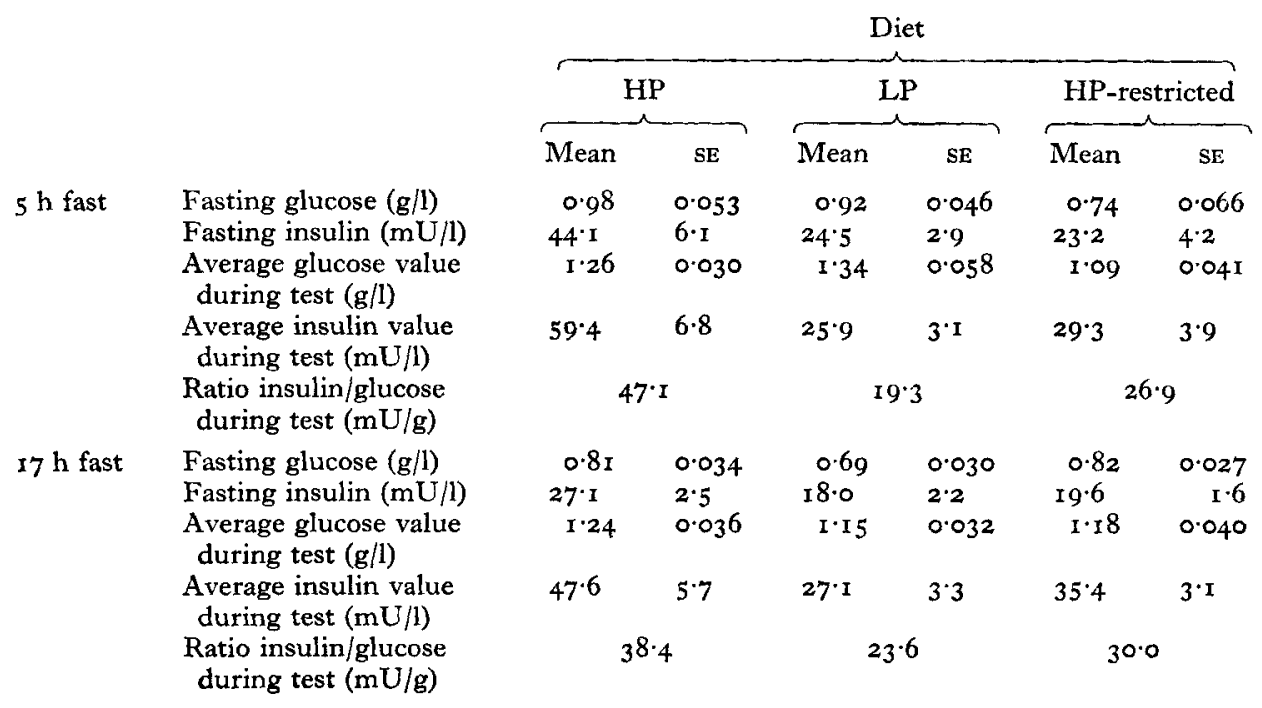




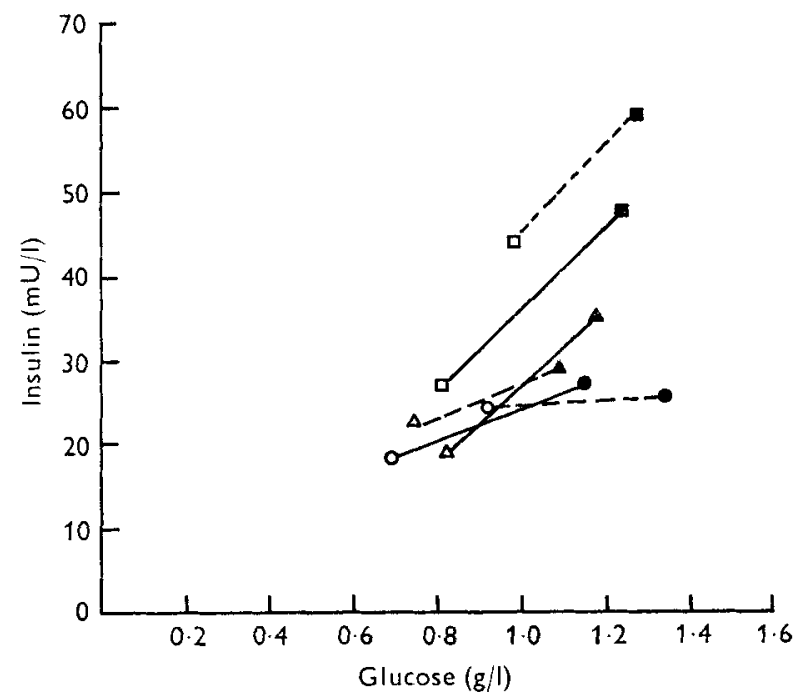

Fig. 4. Fasting values (open symbols) and average values during first hour of oral GTT (closed symbols) for plasma insulin against blood glucose concentration in rats. $\square$, The HP diet ad lib.; $\bigcirc$, the LP diet $a d l i b$.; $\triangle$, the HP diet pair-fed approximately to the intake of rats given the LP diet (HP-restricted). Prior to the oral GTT the rats were fasted for either $5 \mathrm{~h}(---)$ or $17 \mathrm{~h} \mathrm{(-)}$.

\section{Muscle aminotransferases}

Aspartate amino transferase. Although there were quantitative differences between experiments, in the levels of enzyme activity found, each experiment consistently showed no effect of diet (Table 7).

Alanine aminotransferase. All malnourished animals showed reduced activity of this enzyme, so that the treatment effect was highly significant and consistent (Table 7 ).

\section{$I / G$ ratio during oral GTT}

Oral glucose loads given to rats which had been fasting for $5 \mathrm{~h}$ or $\mathrm{I} 7 \mathrm{~h}$ resulted in higher I/G ratios for HP rats than for those in other groups (Table 8). Analysis showed that of the two variables (glucose and insulin), differences in the $I / G$ ratio were due to the effects of dietary treatment on the concentration of insulin rather than on that of glucose (Fig. 4).

\section{DISCUSSION}

The main interest in this work is in the comparison of the two chronically malnourished groups of rats (LP and HP-restricted). Rats in the first of these groups had to adapt to a diet of very low protein value, and the rats in the second group to inadequate amounts of a potentially adequate diet. These dietary regimens were chosen as representing the two commonest nutritional causes of protein-energy malnutrition (PEM). They were chosen also because of the expectation that some of the biochemical changes developing in the rats would reflect suppression of gluconeogenesis in the LP group, to which carbohydrate was freely availabe (if not consumed), and enhancement 
of gluconeogenesis in the HP-restricted rats, in which energy restriction was a known factor. In particular it was expected that the livers of the LP and HP-restricted rats would show, respectively, high and low concentrations of glycogen, and low and high activities of glucose-6-phosphatase, thus producing a model relevant to the discussion of similarly contrasting results for children suffering from PEM (Alleyne \& Scullard, I969).

Only in Expt 2 (Table 6) were the expected results obtained for glycogen. More commonly there were wide variations, probably relating simply to the immediately preceding balance between energy intake and expenditure as evidenced by the very low hepatic glycogen levels in the acutely fasted rats (HP-fasted).

On the other hand the predicted results were obtained for hepatic glucose-6phosphatase activity which was consistently lowest in rats fed on the LP diet (Table 6). As with pigs (Heard, I966), this effect was greatest in those rats which were youngest when the LP diet was first offered (Expt 3). This accords with the fact that activity is low in the neonate and increases after birth (Walker, 1966). Apart from low-protein high-carbohydrate diets the only other factor known to reduce hepatic glucose-6phosphatase activity is insulin administration (Ashmore \& Weber, I968), but as discussed later this is unlikely to be a factor in malnutrition. In contrast to these conditions which are associated with low activity of glucose-6-phosphatase, enhanced activity is associated with increased gluconeogenesis. This occurs in conditions characterized by net loss of muscle protein, e.g. diabetes, cortisol administration and starvation (Ashmore \& Weber, I968). Somewhat surprisingly, in the present work, mean glucose-6-phosphatase activity was only marginally elevated in rats offered the HP-restricted diet and not affected at all by acute fasting (HP-fasted). Therefore although there was a consistent contrast between the effects of the LP and HP-restricted diets this was due primarily to the depression of hepatic glucose-6-phosphatase in LP rats.

The other enzymes measured, aspartate aminotransferase and alanine aminotransferase, also have a role in gluconeogenesis. In the liver, alanine aminotransferase activity closely paralleled that of glucose-6-phosphatase (except in the HP-fasted group) (Table 6). The changes in alanine aminotransferase activity were even more marked and consistent because in this case not only did the LP diet cause a marked depression but the HP-restricted diet also caused an equally marked elevation in enzyme activity. Aspartate aminotransferase differed in that the LP rats showed no fall in activity in their livers, and indeed showed a marginal increase compared with the HP group.

Das \& Waterlow (1974) on the other hand reported that the activity of hepatic aspartate aminotransferase fell at exactly the same rate as that of alanine aminotransferase on changing rats from HP to LP diets. Since Das \& Waterlow (1974) had used an enzymatic method and we had used a chemical method for assaying keto acids formed in the aminotransferase reaction, a separate experiment was carried out in which both methods were used to measure enzyme activity. The results (Table 9) which showed good correlation between the two methods $(r 0.68, P<0.0$ f for aspartate aminotransferase; $r 0.92, P<0.00 \mathrm{r}$ for alanine aminotransferase) conformed 
Table 9. Comparison of chemical and enzymatic methods for determining hepatic aspartate aminotransferase (EC 2.6.I.1) and alanine aminotransferase (EC 2.6.1.2) activities (units/g liver) in young rats for 4 weeks either a high-protein $(H P)$ diet ad lib., a low-protein $(L P)$ diet ad lib., or the HP diet pair-fed approximately to the intake of rats given the LP diet (HP-restricted)

(Mean values with their standard errors for six rats/group)

\begin{tabular}{|c|c|c|c|c|c|c|c|}
\hline & & & & & & & \\
\hline & & & & & & HP-re & cted \\
\hline Measurement & Method & Mean & SE & Mean & SE & Mean & SE \\
\hline Aspartate aminotransferase & $\begin{array}{l}\text { Chemical } \\
\text { Enzymatic }\end{array}$ & $\begin{array}{l}41 \cdot 7 \\
71 \cdot 0\end{array}$ & $\begin{array}{l}2 \cdot 06 \\
3 \cdot 13\end{array}$ & $\begin{array}{l}40 \cdot 9 \\
83.8\end{array}$ & $\begin{array}{l}3.90 \\
2.72\end{array}$ & $\begin{array}{r}70.3 \\
115.8\end{array}$ & $\begin{array}{l}5 \cdot 56 \\
7 \cdot 54\end{array}$ \\
\hline Alanine aminotransferase & $\begin{array}{l}\text { Chemical } \\
\text { Enzymatic }\end{array}$ & $\begin{array}{l}5.08 \\
2 \cdot 82\end{array}$ & $\begin{array}{l}0.62 \\
0.27\end{array}$ & $\begin{array}{l}\mathrm{I} \cdot 67 \\
\mathrm{I} \cdot 89\end{array}$ & $\begin{array}{l}0.35 \\
0.17\end{array}$ & $\begin{array}{r}14 \cdot 92 \\
8 \cdot 03\end{array}$ & $\begin{array}{l}I \cdot 16 \\
0.61\end{array}$ \\
\hline
\end{tabular}

with those given earlier (Table 6). Therefore the reason for the differences between our findings and those of Das \& Waterlow (1974) does not lie in methodology.

Confidence in our findings was strengthened by a report of liver enzyme activity during late pregnancy in the rat (Diamant $\&$ Shafrir, 1972). Here also the activity of alanine aminotransferase was depressed while that of aspartate aminotransferase was elevated. This afforded another example of the way in which the last stages of pregnancy mimic, in the mother, signs found in PEM in infants (e.g. anaemia, water retention, increased adrenocortical activity, increased liver fat and impaired glucose tolerance).

In LP rats, alanine aminotransferase activity was very significantly reduced in muscle as well as in liver. The two other malnourished groups (HP-restricted and HP-fasted) also showed some reduction in muscle enzyme activity, in contrast to their results for the liver. Muscle aspartate aminotransferase appeared to be unaffected by any of the dietary stresses.

The particular sensitivity of alanine aminotransferase to dietary change reflects the importance of alanine in the transfer of amino groups from muscle to liver under conditions of active gluconeogenesis. In prolonged starvation, and therefore probably also in chronic restriction of energy intake (HP-restricted), amino acid mobilization in muscle is eventually reduced, leading to lowered substrate supply to the liver. But in the liver the fractional removal rate of alanine is maintained or increased, so that there is a specific fall in plasma alanine concentration (Felig, Owen, Wahren \& Cahill, 1969). Our findings of decreased plasma alanine concentrations and increased alanine aminotransferase activities in the HP-restricted and HP-fasted rats fit into this general picture (Tables 6 and 7 and Fig. $3 b$ ). In LP rats, near normal plasma alanine levels and depression of the activities of alanine aminotransferase in liver and muscle and hepatic glucose-6-phosphatase, all point to marked depression of gluconeogenesis.

Of the other biochemical measurements at post-mortem, the most significant and consistent changes were found in haemoglobin, plasma protein, plasma insulin (all in LP animals) and liver fat (consistently elevated in LP animals). Haemoglobin, plasma protein and liver fat concentrations were usually normal in the HP-restricted rats, and 
usually elevated in the HP-fasted group. Fasting plasma insulin concentrations were reduced in the HP-restricted and HP-fasted groups but not usually to quite the same extent as in the LP group.

Although water was available for the fasted rats, the higher haemoglobin and plasma protein concentrations in this group suggest some degree of dehydration. In their increased concentration of fat, livers in the fasted rats show a superficial resemblance to the livers of the LP rats, but the mechanisms of fat accumulation in the two types of animals are likely to be quite different. Elevated plasma fatty acid concentrations in fasting would, for a time, lead to increased hepatic lipid synthesis. In the LP animals plasma-free fatty acid concentrations were below normal and the picture is more likely to be one of impairment in the release of lipid from the liver (Waterlow \& Alleyne, 1971).

The biochemical differences between the HP, LP and HP-restricted rats are consistent with the differences observed between normal children, children with kwashiorkor and marasmic children respectively, the main discrepancy being the relatively minor degree of fat accumulation (though highly significant statistically) in the LP group.

Adding to the weight of these resemblances between the animal models and malnourished infants are two other sets of findings, the insulin response to glucose, and plasma amino acid concentrations.

Oral glucose tolerance tests showed no consistent effect of dietary treatment on blood glucose concentrations before or during the test, but there was a highly significant treatment effect on plasma insulin levels, both fasting and during the test, the malnourished rats having the lower values (Fig. 4). The result was that the $I / G$ ratio during the oral glucose tolerance test was markedly lower in LP rats than in HP rats, and also reduced, but less severely so, in the HP-restricted animals. Only absolute values for glucose and insulin were used (Table 8) because when increments above fasting were calculated some values were negative, particularly after only $5 \mathrm{~h}$ fast. Probably $5 \mathrm{~h}$ was too short a period of time for hormone and metabolite levels to reach post-absorptive stability, whereas after $17 \mathrm{~h}$ fast, insulin levels were similar in the three dietary groups and formed a better base line for testing insulinogenic capacity.

The LP rats in the present experiment probably resembled the LP pigs of our earliest work (Heard, 1966) rather than the later LP dogs which were much less severely malnourished and in which elevated rather than depressed insulin levels were found after glucose (Heard \& Henry, r969).

The LP component of the rat model used in the present work strongly resembles that reported by Stead \& Brock (1972) and Weinkove, Weinkove \& Pimstone (1976), in regard to formulation of diet, the use of young animals and the biochemical consequences of the LP diet. In particular there is agreement on hypoalbuminaemia, increased fat accumulation in the liver, and impaired insulinogenic response to glucose. The Cape Town workers did not include pair-fed controls, but by comparison with normal weanling animals, which served as weight-controls, Weinkove et al. (1976) have shown that $\beta$-cell malfunction in the LP rats is not due to functional immaturity.

In the present work the patterns of boichemical changes found in both the LP animals 
and HP-restricted animals are associated with diminished insulin levels. This does not support Whitehead \& Alleyne's (1972) contention that relative hyperinsulinaemia explains the characteristic biochemistry of kwashiorkor as compared with marasmus. Our results are in line with those of workers in Cape Town (Becker, Pimstone, Hansen \& Hendricks, 197I; Becker, Pimstone, Hansen, MacHutchon \& Drysdale, 1972) who found, using the oral GTT, that I/G ratios were consistently reduced in kwashiorkor and usually but not always so in marasmus. They also presented evidence that the insulinogenic response was greater to intravenous glucose than to oral glucose. This aspect was not explored in the present work.

In regard to plasma animo acid concentrations, Fig. 2 shows the close resemblance between the patterns for $\mathrm{LP}$ rats and for a child suffering from kwashiorkor. A very similar pattern had previously been reported for puppies fed on diets of low protein value (Platt, I968). Fig. $3(a)$ shows the contrast between plasma amino acid patterns in LP and HP-restricted rats, with much greater preservation of essential amino acids in the latter group. When casein is supplemented with methionine, as in the diets used in this work, threonine becomes the limiting amino acid, and this is reflected in very low plasma threonine concentrations in the LP rats. Interestingly, in the HPrestricted rats, although they also had a reduced protein intake, plasma threonine concentration was not nearly so severely affected. The unique position of the LP rats in respect to plasma amino acid concentrations was reflected not only in absolute values but also in the ratio of non-essential to essential amino acids and in the phenylalanine:tyrosine ratio (Table 5). Both these ratios have been found to be elevated in kwashiorkor and both were markedly raised in the LP rats, and much less affected in the HP-restricted animals.

Table ro presents the results of analysis of variance carried out on eleven of the responses measured in the three experiments. There are two main sources of variation: (I) different experiments, and (2) different dietary treatment. Differences between experiments reflect inherent biological variability between different batches of rats bought commercially, including variations due to age and size at the start of the experiment (Table 3). More important, however, were large and consistent effects of dietary treatment which were evident in 8 of the II response variables. In one of the others (liver fat) the dietary effect was consistent in direction but not in size. In the two cases where interaction was detected we were unable to explain this in terms of differences in food intake. Therefore, it would appear that the failure to achieve perfect pair feeding (Table 3 ) did not appreciably affect the results.

The main object of this work was therefore achieved in that this simple rat model consistently showed a number of characteristic biochemical responses to each of the four dietary regimens. The fact that the conditions chosen result in signs which mimic those found in kwashiorkor (LP) and marasmus (HP-restricted) may be regarded as a bonus to those who are interested in these human diseases, and who are seeking a useful animal model.

A criticism often levelled against animal models of PEM is their inability to reproduce the really fatty liver of kwashiorkor. Because animals have, even when undernourished, the capacity to move glucose from blood into peripheral tissues at 
Table 10. Results of analysis of variance showing significance of effects of dietary treatment, experiment, and interaction on measurements made in blood, liver and muscles of young rats given for 4 weeks either a high-protein $(H P)$ diet ad lib., a low-protein $(L P)$ diet ad lib., the HP diet pair-fed approximately to the intake of the rats given the LP diet (HP-restricted), the HP diet ad lib., followed by a $48 \mathrm{~h}$ fast (HP-fasted), in three different experiments

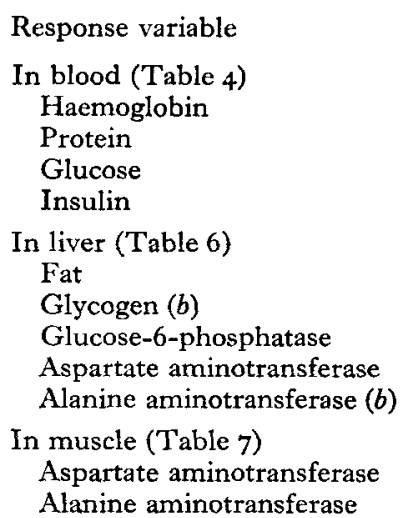

\begin{tabular}{ccc}
\multicolumn{3}{c}{ Significance of effect of } \\
Dietary treatment & Experiment & Interaction \\
$* * *$ & $* * *$ & NS \\
$* * *$ & $* * *$ & NS \\
NS & $* * *$ & NS \\
$* * *$ & $* * *$ & \\
& & $* *(a)$ \\
$* * *$ & $* *$ & $* *(a)$ \\
$* * *$ & $* * *$ & NS \\
$* * *$ & $* * *$ & NS \\
$* * *$ & NS & \\
& & NS \\
NS & $* * *$ & NS \\
$* * *$ & $* * *$ &
\end{tabular}

*** $P<0.001, * * P<0.01, * P<0.05$.

NS, non-significant.

(a) not explained by food intake.

(b), log transformation to stabilize variance.

a rate which is as great as in the healthy human subject, they are likely to maintain peripheral re-esterification of fatty acids much more efficiently than malnourished children do (Heard, I966; Heard \& Turner, I967; Asato, Heard \& Sketcher, 1974). Thus the availability of substrate for hepatic lipid synthesis would be less in malnourished animals than in infants suffering from kwashiorkor. In malnourished animals further diminution in glucose utilization may be induced by the diabetogenic agent streptozotocin, and this does result in an intensely fatty liver (C. R. C. Heard, unpublished results).

In comparing the results of animal models with the biochemstry of human malnutrition, it is instructive to reflect on the two all-important non-biochemical signs of malnutrition in these rat ' communities'. These are: (I) greatly reduced rate of growth; (2) greatly reduced food intake. Mean body-weights as a percentage of the HP groups were, for the three experiments: LP $37,3^{8}$ and $29 \%$; HP-restricted 58,53 and $44 \%$. Mean food intakes, again as a percentage of the HP group, were: LP 63, 58 and $39 \%$; HP-restricted 50, 57 and $44 \%$. Both the LP and HP-restricted rats were therefore severely stunted and both equally short of food (energy) as judged by normal requirements (HP). Yet the HP-restricted group gained significantly more weight concomitantly with marked biochemical signs of gluconeogenesis, i.e. of energy deprivation. This difference from the LP rats was due to the extra protein they received, although in terms of gross protein intake this was only $50 \%$ of requirement (the same restriction 
Table II. Mean energy intake $\left(M \mathcal{Y} / \mathrm{kg}^{0.73}\right.$ per $\left.d\right)$ in rats given for 4 weeks either a highprotein (HP) diet ad lib., a low-protein (LP) diet ad lib., or the HP diet pair-fed approximately to the intake of rats given the LP diet (HP-restricted)

(Derived from Table 3 , using total energy intake and the mean of initial and final body-weights)

$\begin{array}{lllc}\text { Expt } & \text { HP } & \text { LP } & \text { HP-restricted } \\ \text { I } & \text { I.055 } & \text { I.085 } & 0.699 \\ 2 & \mathrm{I} \cdot 075 & 0.985 & 0.835 \\ 3 & \mathrm{I} \cdot 2 \mathrm{I} 6 & 0.955 & 0.867 \\ \text { Mean } & \mathrm{I} \cdot \mathrm{II5} & \mathrm{I} \cdot 008 & 0.800 \\ \text { Comparison with published work } & & & \\ \quad\left(\mathrm{kcal} / \mathrm{kg}^{0.73} \text { per d) }\right. & & & \\ \quad(a) & 266 & 24 \mathrm{I} & \text { I9I } \\ \quad(b) & 249 & 226 & -\end{array}$

(a) Present work, mean for all three experiments.

(b) From Table 4 of Stead \& Brock (1972); I rat/cage.

as for energy). In the LP group, gross protein intake was reduced still further, to about $17 \%$ of requirement, and growth was minimal, despite the same energy intake as the HP-restricted rats.

We have related protein and energy intakes to absolute requirements, measured in terms of the voluntary intake of the control rats (HP). Stead \& Brock (1972) on the other hand, related their results to body-weight ( $\mathrm{kcal} / \mathrm{kg}^{0.73}$ per $\mathrm{d}$ ). The mean daily energy intake was therefore calculated in this way for our rats. The results are shown in Table I I, and they are very similar to those of Stead \& Brock (1972) for individually housed animals, which all ours were. It is confirmed that, on this basis, the energy intake of LP rats is only marginally less than that of HP animals. On the other hand, the HP-restricted rats showed a significant deficit in energy intake in relation to body-weight and this correlated with marked increase in the activity of gluconeogenic enzymes and an amino acid pattern related to that of prolonged fasting. Yet despite all this the animals grew appreciably faster than the LP rats, indicating a greater efficiency of energy utilization in the HP-restricted rats. It is equally important to note that the LP animals in these experiments did not show abnormally high energy intakes relative to body-weight, so that increased liver fat and marked suppression of gluconeogenesis cannot be explained by relatively excessive energy intake; if anything, energy intake was reduced.

There has been disagreement over the relative importance of protein deficiency and energy deficiency, and over the question of whether infants destined to develop kwashiorkor have a higher energy intake than those who will develop marasmus (Gopalan, 1968). The present work suggests that there need be no great difference in energy intake, which, in absolute terms, may be equally low in the two conditions. It"reminds us that protein is still of importance even under conditions of extreme energy deprivation, and that rehabilitation or improvement of the diet of either group of animals would require both energy and protein.

Without precise knowledge of protein and energy requirements and intake, 
classification of PEM is fraught with difficulty. These problems are increased by differences in the age of onset of deficiency and effects of maternal malnutrition. The present work suggests that the problem might be approached biochemically. The LP and HPrestricted groups of rats would represent conditions near the ends of a biochemical spectrum. At one end gluconeogenesis is markedly suppressed and this is accompanied by general derangement of liver function (e.g. hypoalbuminaemia and increased accumulation of fat), and by biochemical signs of deficiency of essential amino acids. At the other end of the spectrum liver function is maintained and gluconeogenesis is markedly enhanced, essential amino acid levels in the plasma are mostly near normal, but the plasma alanine concentration falls. Both extremes are possible with a low energy intake, but suppression or enhancement of gluconeogenesis is dependent on the carbohydrate-protein balance in the diet. This simple picture would almost certainly be distorted by infections or intermittent starvation, but the work of Coward \& Whitehead (1972) with baboons tends to support the view that such crises would drive the metabolic responses still further towards the nearer end of the spectrum rather than reverse the process. Clearly, this is an area where conjecture exceeds the evidence.

We are grateful to Professor J. C. Waterlow, Head of the Department of Human Nutrition, for encouragement in this work, to Mr P. Broadbent for plasma amino acid analyses, to Miss Margaret Harrison for help in the care of animals, and to Dr Janet Catterick for help in processing the data for computer analysis.

\section{REFERENCES}

Alleyne, G. A. O. \& Scullard, G. H. (1969). Clin. Sci. 37, 631.

Asato, L., Heard, C. R. C. \& Sketcher, R. D. (r974). Proc. Nutr. Soc. 33, I I A.

Ashmore, J. \& Weber, G. (r968). In Carbohydrate Metabolism and its Disorders, vol. I, p. 336 [F. Dickens, P. J. Randle and W. J. Whelan, editors]. London: Academic Press.

Becker, D. J., Pimstone, B. L., Hansen, J. D. L. \& Hendricks, S. (1971). Diabetes 20, 542.

Becker, D. J., Pimstone, B. L., Hansen, J. D. L., MacHutchon, B. \& Drysdale, A. (I972). Am. F. clin. Nutr. 25, 499.

Broadbent, P. G. \& Heard, C. R. C. (1973). Proc. Nutr. Soc. 32, 48 A.

Coward, D. G. \& Whitehead, R. G. (1972). Br. F. Nutr. 28, 223.

Diamant, Y. Z. \& Shafrir, E. (1972). Biochim. biophys. Acta 279, 424.

Das, T. K. \& Waterlow, J. C. (1974). Br. F. Nutr. 32, 353.

Doell, B. H. (1966). Protein-calorie deficiency and stress. Ph.D. Thesis, University of London.

Durbin, P. A. J., Heard, C. R. C. \& Platt, B. S. (1960). Proc. Nutr. Soc. 19, xxxv.

Felig, P., Owen, O. E., Wahren, J. \& Cahill, G. F. Jr. (1969). F. clin. Invest. 48, 584.

Freedland, R. A. \& Harper, A. E. (1958). F. biol. Chem. 233, I.

Gopalan, C. (I968). In Calorie Deficiencies and Protein Deficiencies, p. 49 [R. A. McCance and E. M. Widdowson, editors]. London: J. \& A. Churchill.

Hales, C. N. \& Randle, P. J. (1963). Biochem. J. 88, 137.

Heard, C. R. C. (1966). Diabetes r5, 78 .

Heard, C. R. C., Frangi, S. M. \& Wright, P. M. (1973). Proc. Nutr. Soc. 32, 47A.

Heard, C. R. C. \& Henry, P. A. J. (1969). F. Endocr. 45, 375.

Heard, C. R. C. \& Turner, M. R. (1967). Diabetes I6, 96.

Holt, L. E., Snyderman, S. E., Norton, P. M., Roitman, E. \& Finch, J. (1963). Lancet ii, 1343.

Kemp, A. \& Kits van Heijningen, A. J. M. (1954). Biochem. F. 56, 646.

Mukherjee, K. L. \& Nath, R. L. (1957). Bull. Calcutta Sch. trop. Med. Hyg. 5, r7o.

Payne, P. R. \& Stewart, R. J. C. (1972). Lab. Anim. 6, 135.

Platt, B. S. (r968). In Calorie Deficiencies and Protein Deficiencies, p. 240 [R. A. McCance and E. M. Widdowson, editors]. London: J. \& A. Churchill. 
Reitman, S. \& Frankel, S. (1957). Am. Y. clin. Path. 28, 56.

Stead, R. H. \& Brock, J. F. (1972). J. Nutr. 102, 1357.

Walker, D. G. (1968). In Carbohydrate Metabolism and its Disorders, vol. I, p. 465 [F. Dickens, P. J. Randle and W. J. Whelan, editors]. London: Academic Press.

Waterlow, J. C. \& Alleyne, G. A. O. (197I). Adv. Protein. Chem. 25, II7.

Waterlow, J. C. \& Weisz, T. (1956). J. clin. Invest. 35, 346.

Weinkove, C., Weinkove, E. A. \& Pimstone, B. L. ( (976). Clinical Science E Molecular Medicine 50, I53.

Whitehead, R. G. \& Alleyne, G. A. O. (1972). Br. med. Bull. $28,72$.

Whitehead, R. G. \& Dean, R. F. A. (1964). Am. F. clin. Nutr. 14, 320.

Woodnott, D. P. (I96I). J. Anim. Techns Ass. 12, 59.

Wootton, I. D. W. (1964). Micro-Analysis in Medical Biochemistry. $4^{\text {th }}$ ed. London: J. \& A. Churchill. 